\title{
The Cost of Low Fertility in Europe
}

\section{Citation}

Bloom, David E., David Canning, Günther Fink, and Jocelyn E. Finlay. 2009. The cost of low fertility in Europe. European Journal of Population / Revue Européenne de Démographie 26, no. 2: 141-158. doi:10.1007/s10680-009-9182-1.

\section{Published Version}

doi:10.3386/w14820

\section{Permanent link}

http://nrs.harvard.edu/urn-3:HUL.InstRepos:33730185

\section{Terms of Use}

This article was downloaded from Harvard University's DASH repository, and is made available under the terms and conditions applicable to Other Posted Material, as set forth at http:// nrs.harvard.edu/urn-3:HUL.InstRepos:dash.current.terms-of-use\#LAA

\section{Share Your Story}

The Harvard community has made this article openly available.

Please share how this access benefits you. Submit a story.

Accessibility 


\title{
Program on the Global Demography of AgING Working Paper Series
}

\section{The High Cost of Low Fertility in Europe}

\author{
David E. Bloom \\ David Canning \\ Günther Fink \\ Jocelyn E. Finlay
}

June 2008

PGDA Working Paper No. 32

http://www.hsph.harvard.edu/pgda/working.htm

The views expressed in this paper are those of the author(s) and not necessarily those of the Harvard Initiative for Global Health. The Program on the Global Demography of Aging receives funding from the National Institute on Aging, Grant No. 1 P30 AGo24409-01. 


\title{
The High Cost of Low Fertility in Europe ${ }^{1}$
}

\author{
David E. Bloom \\ David Canning \\ Günther Fink \\ Jocelyn E. Finlay
}

Harvard School of Public Health

Program on the Global Demography of Aging

June 2008

\begin{abstract}
We analyze the effect of fertility on income per capita with a particular focus on the experience of Europe. For European countries with below-replacement fertility, the high cost of continued low fertility will only be observed in the long run. We show that in the short run, a fall in the fertility rate will lower the youth dependency ratio and increase the working-age share, thus raising income per capita. In the long run, however, the burden of old-age dependency dominates the youth dependency decline, and continued low fertility will lead to small working-age shares in the absence of large immigration inflows. To illustrate these effects we construct a population accounting model and simulate steady-state outcomes. Regression analysis indicates the differing marginal effects of long-term fertility change in Europe versus the rest of the world.
\end{abstract}

\footnotetext{
${ }^{1}$ This paper was prepared for the International Conference on the Economic Consequences of Low Fertility, April $11-122008$ at the University of St. Gallen Switzerland. We are grateful to Rainer Muenz and the participants in the Conference for their helpful comments. We extend our thanks to Mansour Farahani for compiling the family planning data. Support for this research was provided by grant number 5 P30 AG024409 from the National Institute on Aging, National Institutes of Health, and by a grant from the William and Flora Hewlett Foundation.
} 


\section{Introduction}

The impact of demographic change on economic development has long been debated. Although the Malthusian hypothesis that population growth is constrained by available resources held a central position for centuries, the simultaneous occurrence of economic growth and population growth over long periods of time has demanded new models of the interplay between these phenomena (Becker, Glaeser and Murphy, 1999; Galor and Weil, 1999; Galor and Weil, 2000; Galor, 2005). Little consensus has been reached during the last 50 years on the effect of population growth on economic growth. For example, Kelley and Schmidt (1995) find no correlation between population growth and economic development in the 1960s and 1970s, yet find evidence of a negative relationship emerging in the 1980s.

The concept of "optimum population growth" is an old debate (Samuelson, 1975; Deardorff, 1976; Samuelson, 1976). Further debate over the effects of population pressure on economic development remains fervent (Simon, 1996; Ehrlich, 2008). Ehrlich argues that population pressure on natural resources and the environment is a contemporary issue that has been ignored by policy makers. Simon takes an alternative view and stresses the benefits of the technological progress that he argues is a natural concomitant of population growth. Larger populations make innovation more likely, and moreover, increase the scope for technological adoption.

Early work by Bloom and Freeman and by others highlights the importance of analyzing the effect on economic growth of the individual components of population growth: fertility and mortality (Bloom and Freeman, 1988; Kelley, 1988; Brander and Dowrick, 1994; Kelley and Schmidt, 1995). In this paper we highlight the fertility channel, and in particular draw on the experience of European countries.

For many, but not all, countries the decline in fertility in the last 45 years has been rapid. The onset of a rapid fertility decline is a signal that a country is undergoing the demographic transition from high fertility (and high mortality) to low fertility (and low mortality). In Figure 1 we show the change in fertility that occurred between 1960 and 2000 relative to the initial 
fertility rate in 1960. Virtually all countries that had a fertility rate below 5.5 in 1960 experienced a decline in fertility ${ }^{2}$ - these countries are or have been undergoing the demographic transition. Countries that had a fertility rate above 5.5 in 1960 either experienced rapid decline in fertility and thus are part of the demographic transition trajectory, or maintained high fertility rates and remain today in a high-fertility and high-mortality state.

Figure 1: Change in total fertility rate 1960-2000

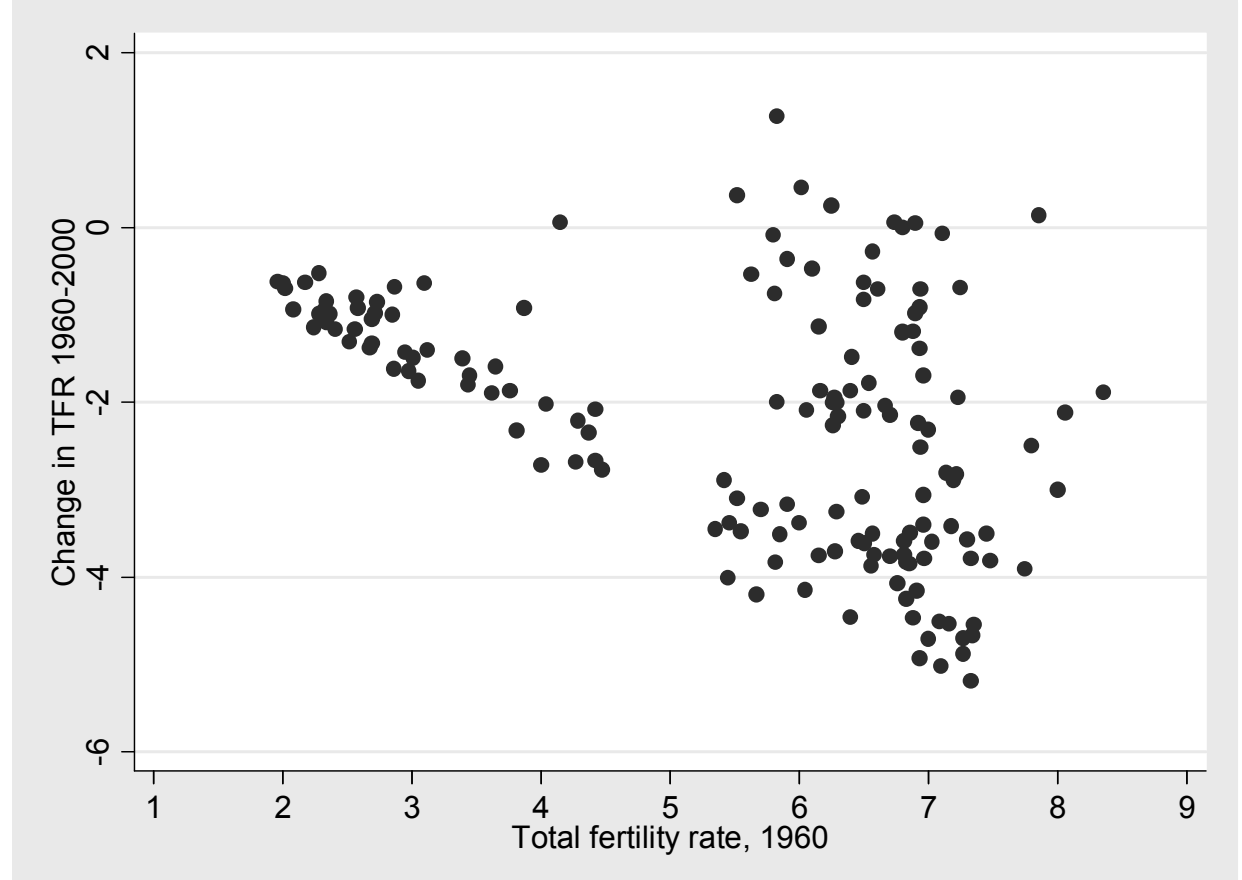

Source: World Bank (2007)

To highlight the change in fertility in Europe between 1960-2000 Figure 2 illustrates the same relationship as in Figure 1 for the European countries.

\footnotetext{
${ }^{2}$ Gabon is an exception to this pattern.
} 
Figure 2: Change in total fertility rate (TFR) 1960-2000 in Europe

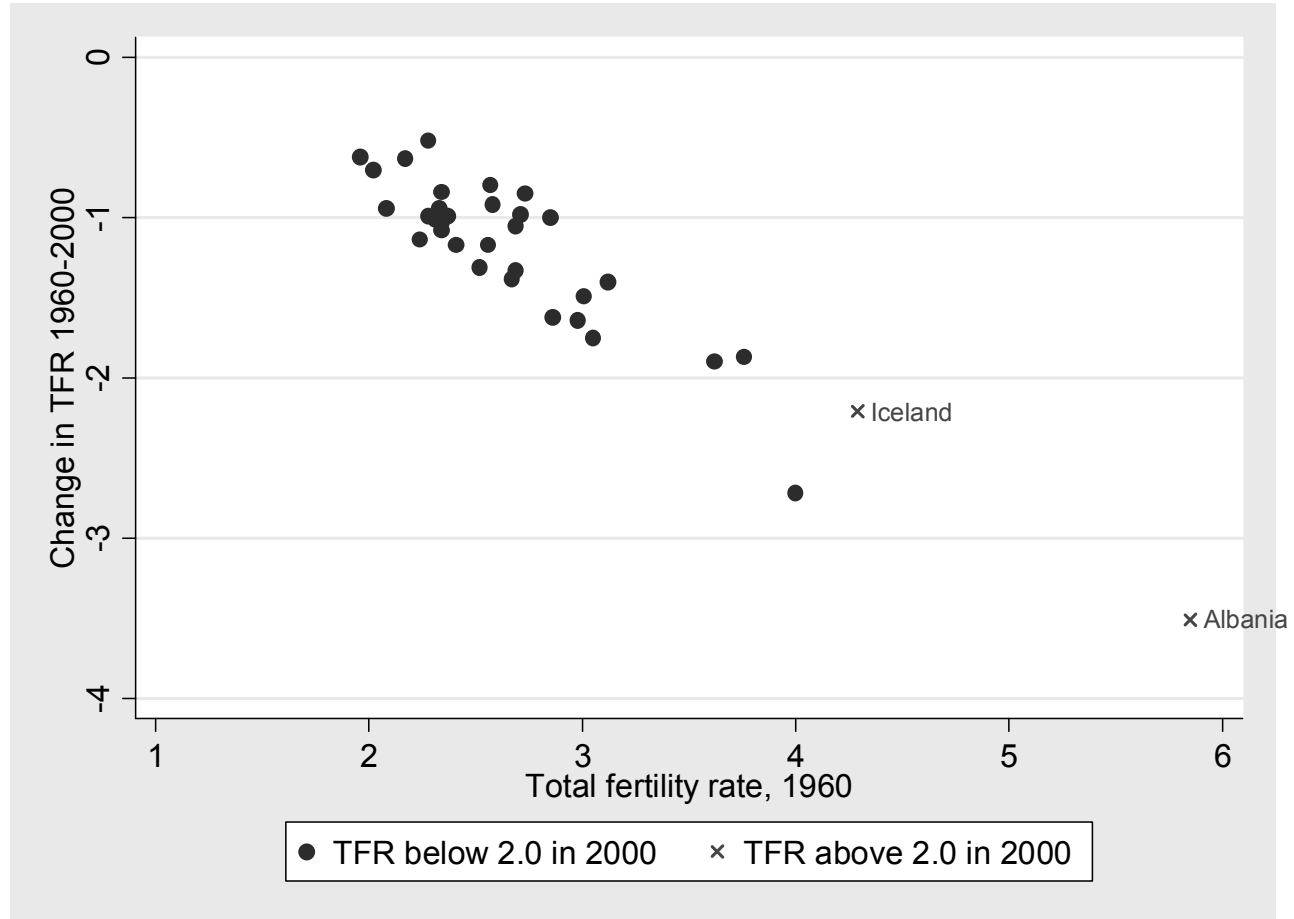

Source: World Bank (2007)

In 1960, Estonia was the only European country to have a total fertility rate below two, at 1.96. Today all but two countries in Europe (Albania and Iceland) have a total fertility rate below two. The reasons for the rapid decline in fertility in Europe, and its decline to "lowest of the low" rates are varied (Lesthaneghe and Willems, 1999; Kohler, Billari and Ortega, 2002; Billari, Frejka, Hobcraft, Macura and van de Kaa, 2004; Billari and Kohler, 2004; Aarssen, 2005; Adsera, 2006; Adsera, 2006; Bjorklund, 2006; Coleman, 2006; Kohler, 2006; McDonald, 2006; Feyrer, Sacerdote and Stern, 2007). Fertility decline in Europe is thought to be due to socioeconomic incentives to delay childbearing, a decline in the desired fertility rate, and institutional factors (labor market rigidities, lack of child care, changing gender roles) (Bongaarts and Bulatao, 1999; Kohler, Billari et al., 2002; Garrido and Malo, 2005; Kohler, 2006). Eastern European societies have also undergone major economic, political and social change.

Eastern and Western European countries share an important demographic feature: belowreplacement fertility. The economic consequences of below-replacement fertility are not well understood. In this paper, we aim to analyze this relationship. We argue that while declines in 
fertility generally induce positive economic outcomes in the short run, the same is not necessarily true in the long run. In the long run, below-replacement fertility is likely to lead to age structures that are sub-optimal with respect to their economic growth implications. The exact magnitude of these effects depends on a host of demographic, social, and political factors that critically shape the long-term development of age structure as well as the interactions between age structure and the economy.

The analysis in this paper naturally links to previous work on the "low fertility trap" that investigates the labor force consequences of low fertility (Billari and Kohler, 2004; Lutz and Skirbekk, 2005; McDonald, 2006). McDonald (2008) argues that when fertility rates are below 1.5 , it is difficult to raise fertility, due to changes in norms (through socialization) and preferences regarding the number of children. Moreover, increased opportunities for women in the workplace coupled with heightened consumerism, and the demographic, mechanical effect of fewer women entering the childbearing age group have contributed to persistently low birth rates. Open for debate among these authors is the threshold fertility rate at which countries enter the "trap" and how countries can escape the trap.

In this paper we do not model the dynamics of fertility directly, but rather explore the long-term relationship between fertility rates and the relative size of the workforce. We thus formalize and generalize the issues and concerns raised by the above literature, without making specific assumptions regarding the long-term determinants of family size.

The rest of the paper is structured as follows: in section 2, we discuss the basic mechanisms through which fertility affects economic growth and highlight the non-linear long run relationship between fertility and the working-age share. In section 3, we discuss recent trends in fertility and the working-age share in Europe and show that working-age share has not fallen yet despite fertility rates below replacement. In section 4 , we use a panel data set covering the period 1960 to 2000 to estimate the (reduced form) effect of fertility on output per capita in Europe. We reflect on these results in section 5. 


\section{Theoretical Background}

\subsection{Overview}

There are three theoretical channels through which fertility affects economic development: population growth with fixed resources (the Malthusian theory), the Solow capital stock effect, and the age structure effect. According to the Malthusian hypothesis, larger populations imply lower resources per capita in the presence of a fixed factor (land is frequently given as example), and thus lower income per capita. A similar, yet slightly more subtle mechanism is at play in the Solow growth model (Solow, 1956) where capital stock is built up through savings and declines with depreciation. With constant returns to scale, population growth works in the same way as capital depreciation and thus lowers steady-state income per capita in the traditional Solow model.

The third link between fertility and economic growth, and the main focus of this paper, is age structure. The age structure of a population follows from the historical sequence of fertility, mortality, and net migration, and directly determines the relative size of the working-age population. Since output is measured in per capita terms, the fact that labor force participation rates vary by age means that the working-age share directly affects income per capita through the number of workers per capita. A decline in fertility reduces the number of children, thus unambiguously raising the working-age share and - as long as participation rates do not change increasing labor supply in the short run (Bloom and Freeman, 1988).

The same argument does not hold in the long run. As we show in further detail below, persistently high fertility rates imply an age distribution strongly skewed towards the young generations in steady-state. Sustained low fertility rates like the ones currently observed across Europe, on the other hand, imply very large relative sizes for the old and economically inactive cohorts in steady-state. 


\subsection{A Simple Model of Age Structure}

The intuition for the basic mechanism linking fertility rates and age structure in the long run can best be provided by a simple population model. Assume a stable population ${ }^{3}$ with three age groups: the young, the middle age, and the old, and normalize the middle age group to unit size. Assuming a 1:1 male/female and a constant fertility rate $f$, we must have $\frac{2}{f}$ people in the old age group, ${ }^{4}$ and $\frac{f}{2}$ people in the young group. The simple age distribution of the population in equilibrium is then given by

$$
\left\{\frac{f}{2}, 1, \frac{2}{f}\right\} .
$$

Assuming that only the middle age group works, the working-age share $w$ of the population can be defined as

$$
w=\frac{1}{\frac{f}{2}+1+\frac{2}{f}}=\frac{2 f}{f^{2}+2 f+4}
$$

This expression has some intuitive properties. First, at replacement fertility, ${ }^{5}$ the working-age share is $1 / 3$. Second, deviations from replacement rate fertility unambiguously lead to a decline in the working-age share. For high fertility rates, the first term in the denominator ( $f / 2)$ becomes large; this is the typical developing country scenario with high youth dependency and very low old-age dependency ratios. With fertility rates below replacement, the last term in the denominator $\left(\frac{2}{f}\right)$ becomes large, capturing the burden of very large old cohorts relative to the size of the working-age cohorts. Figure 3 illustrates the theoretical relationship between stable population fertility rates and working-age shares expressed in equation (2).

\footnotetext{
${ }^{3}$ A stable population refers to a population that has constant age-specific fertility and mortality rates, which, in the absence of migration, implies a constant age structure and constant population growth.

${ }^{4}$ The total number of births is the age-group-specific population times $\mathrm{f} / 2$. Thus, to get a birth cohort size of 1 , we need a "parent cohort" population of $2 / \mathrm{f}$.

${ }^{5}$ In the case with zero mortality before old age, replacement fertility equals 2 .
} 
Figure 3: Theoretical long-run relationship between stable population working-age shares and fertility

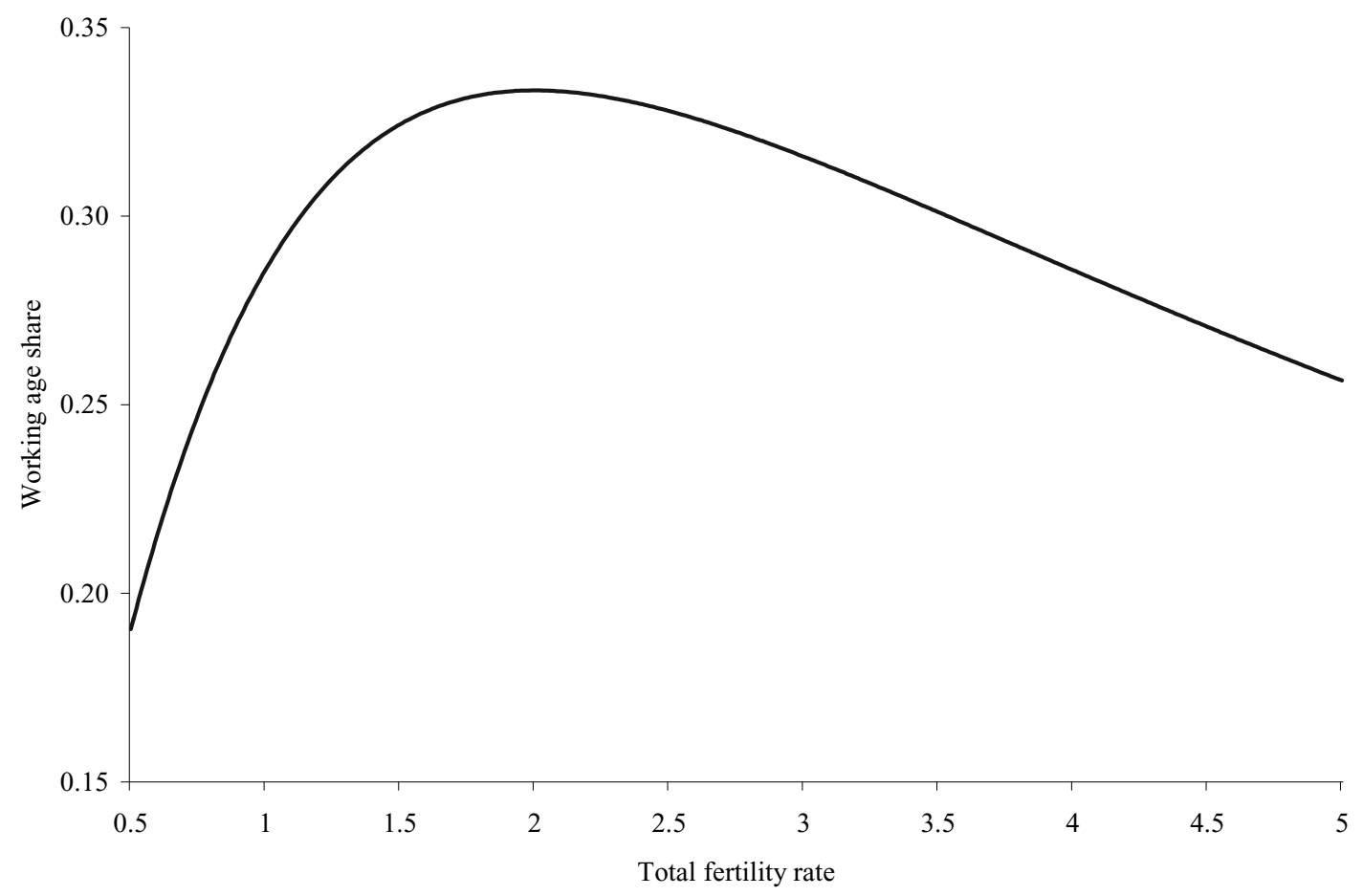

The basic mechanism outlined in our simple model has ignored two important influences on the age structure: mortality and migration. Incorporating mortality in the basic framework is relatively easy: high mortality rates have two principal effects: first, they lower the number of females reaching age 45 and thus being able to complete their fertility cycle; as a result, the number of births generated by a given total fertility rate declines. High infant mortality thus has very similar effects to lower TFR from a stable population perspective.

The second mortality effect comes through aging. Let us define $\sigma$ as the old-age survival rate. Then one can rewrite the equation as

$$
w=\frac{1}{\frac{f}{2}+1+\sigma \frac{2}{f}}=\frac{2 f}{f^{2}+2 f+4 \sigma}
$$


with $\sigma \leq 1$. Lower old age survival implies a lower old-age dependency ratio and thus a higher working-age share. Solving for the fertility rate that maximizes working-age share in steady-state, we get the following first-order condition

$$
\frac{\partial w}{\partial f}=\frac{-2 f^{2}+8 \sigma}{\left(f^{2}+2 f+4 \sigma\right)^{2}}=0,
$$

The working-age share maximizing steady-state fertility rate $f^{*}$ is thus given by

$$
f^{*}=2 \sqrt{\sigma}
$$

If $\sigma=1$, a total fertility rate $f=2$ is the unique solution ${ }^{6}$. The lower old-age survival, the lower the working-age-share maximizing fertility rate. ${ }^{7}$ This result is intuitive. If the old and the young cohorts are equal in number, a flat age structure (equally sized cohorts) implies the largest possible working-age share. If $\sigma<1$, the relative weight of the old is strictly smaller than the relative weight generated by the young, so that the working-age-share maximizing fertility rate is strictly below 2 .

To further illustrate this point, we simulate stable population outcomes for representative survival schedules for populations at different stages of development. Rather than assuming three broad age groups, we calculate the stock of each age group based on a given fertility and mortality schedule where the working age covers the ages 15-64. For each mortality/fertility schedule, we run the simulations until a stable population distribution is reached ${ }^{8}$. The resulting working-age shares are summarized in Figure 4 below. The graph illustrates the relationship between fertility and working-age share. It is important to emphasize that this is a long-run dynamic. Figures 3 and 4 show that a decrease in fertility rate below the WAS-maximizing level

\footnotetext{
${ }^{6}$ We restrict the domain of our analysis to the set of positive real numbers.

${ }^{7}$ As this fertility rate can be above or below the replacement fertility rate, the working-age-share maximizing stable population fertility rate parameter will lead to positive, zero, or negative population growth. Thus we cannot assert that the fertility rate that maximizes the working-age share is the "optimal" fertility rate - the population growth consequences may impose a negative effect on economic growth.

${ }^{8} \mathrm{We}$ initiate the simulation with a flat age structure, and then impose constant age-specific fertility and mortality rates to impute the stock of each age group in each period. It takes up to 200 simulated periods for age structure to converge to a stable population distribution. In Figure 4 we show the resulting stable population working-age share for three examples of mortality schedules and fertility rates between zero and ten.
} 
leads, in the long run, to a lower working-age share. The short-run transitional dynamics look quite different, since any reduction in fertility will mechanically decrease the youth dependency ratio in the near term. The figures thus compare steady states, and do not illustrate short-run dynamics.

\section{Figure 4: Stable population distribution relationship between fertility and working-age share under different life expectancy scenarios}

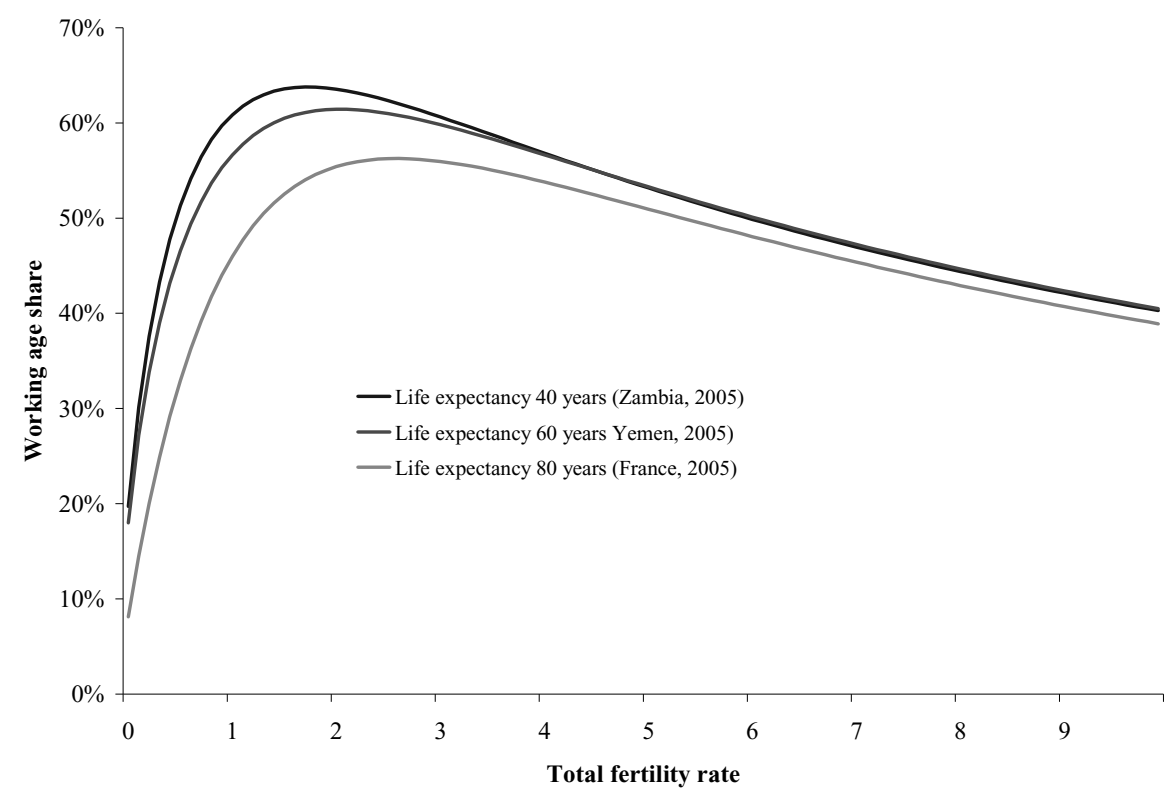

Figure 4 shows the relationship between fertility and working-age shares for three different life tables (World Health Organization): Zambia, with a life expectancy of 40 in 2005, Yemen, with a life expectancy of 60 in 2005, and France, with a life expectancy of 80 in 2005. The figure shows that the basic inverse U-shape relationship between fertility and working-age shares outlined in equations (2) and (3) persists, independent of the mortality schedule applied. It also highlights the differential impact of life expectancies at different levels of fertility. Although life expectancy has very limited effects at very high fertility levels, high levels of old-age survival significantly lower the working-age share for low rates of fertility. As revealed by equation (5), the fertility rate that maximizes the working-age share depends on the relative size of the old cohorts. In Zambia, with a life expectancy of 40 years, youth dependency is more relevant than old-age dependency, so the optimal steady-state total fertility rate is relatively low at 1.7. In Yemen, with a life expectancy of 60 in 2005, the relative burden of the young and the old is similar in magnitude, so that we get an optimal steady-state fertility rate of 2 . The same is 
not true in France; with a life expectancy of 80 years, the burden from the large old generations is greater than the burden from large young generations, so that the working-age-sharemaximizing fertility rate in steady-state is 2.6 , significantly above replacement ${ }^{9}$.

This burden from large generations, however, is dependent on the typical retirement age. In the graphs and calculations made above, we have defined working age as being the age range 15-64. In the European case, a majority of workers retire around 60 (Gruber and Wise, 1999; Gruber and Wise, 2004), so that one may wish to restrict the working age to a smaller range. In Figure 5 we simulate stable population working-age-shares for a range of retirement ages using the French survival schedule. At retirement age 55, the burden of the old is particularly large, implying a working-age-share-maximizing fertility rate of 3.1. If, on the other hand, the working age would go all the way up to age 70, the WAS-maximizing fertility rate would fall to 2.0.

\footnotetext{
${ }^{9}$ It should be noted that the fertility rate maximizing the working-age share may imply growing or declining populations.
} 
Figure 5: Stable population distribution relationship between fertility and workingage share under different retirement age scenarios

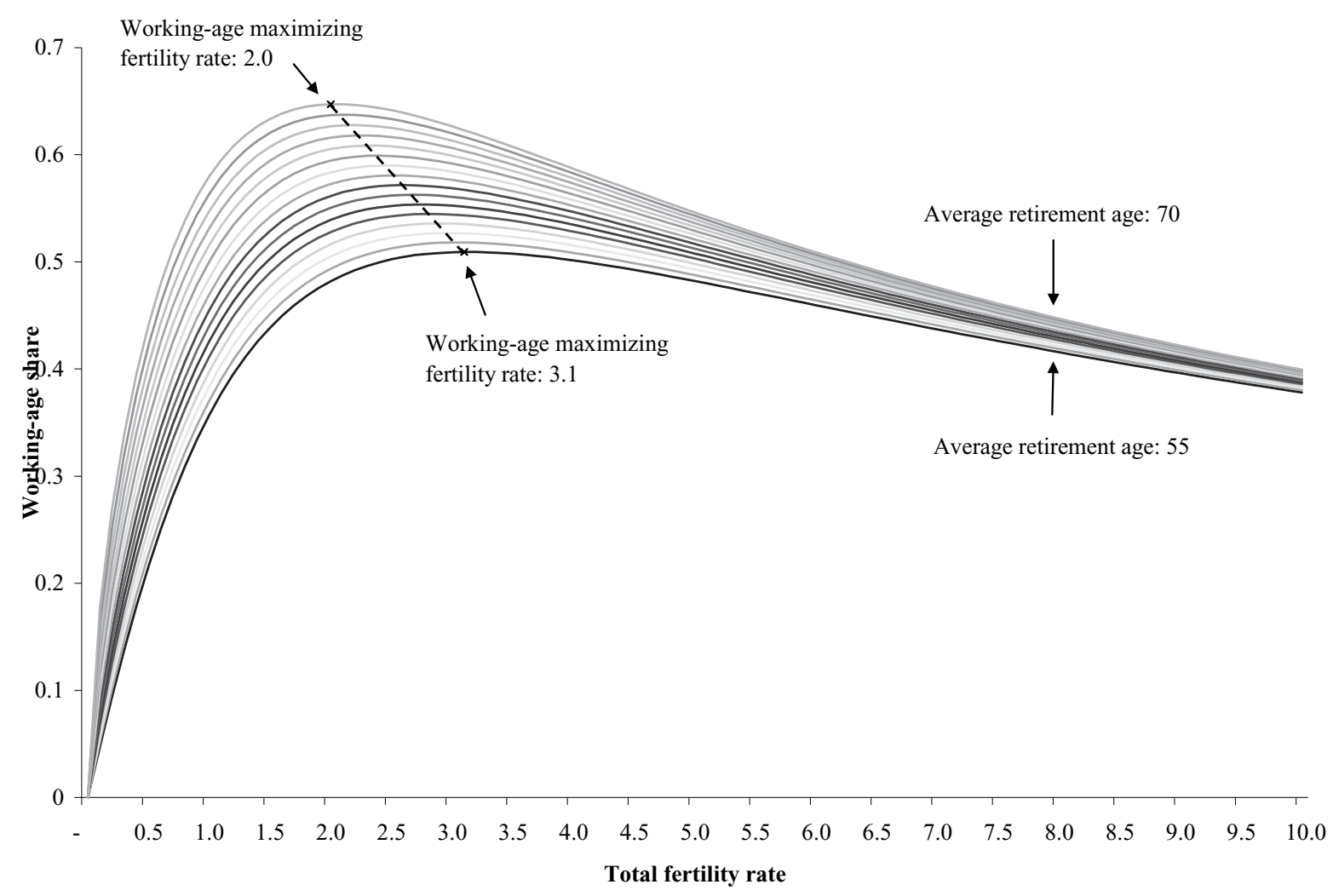

An analogous picture emerges when we change the assumptions regarding the lower bound of the working age to reflect differences in the years of schooling and the resulting differences in the timing of labor force entry. As Figure 6 illustrates, later entry into the labor force mechanically lowers the working-age-share. Later entry into the labor force is associated with a higher relative burden generated by the young cohorts, and thus lower working-age-sharemaximizing fertility rates. 
Figure 6: Stable population distribution relationship between fertility and workingage share under different labor force entry age scenarios

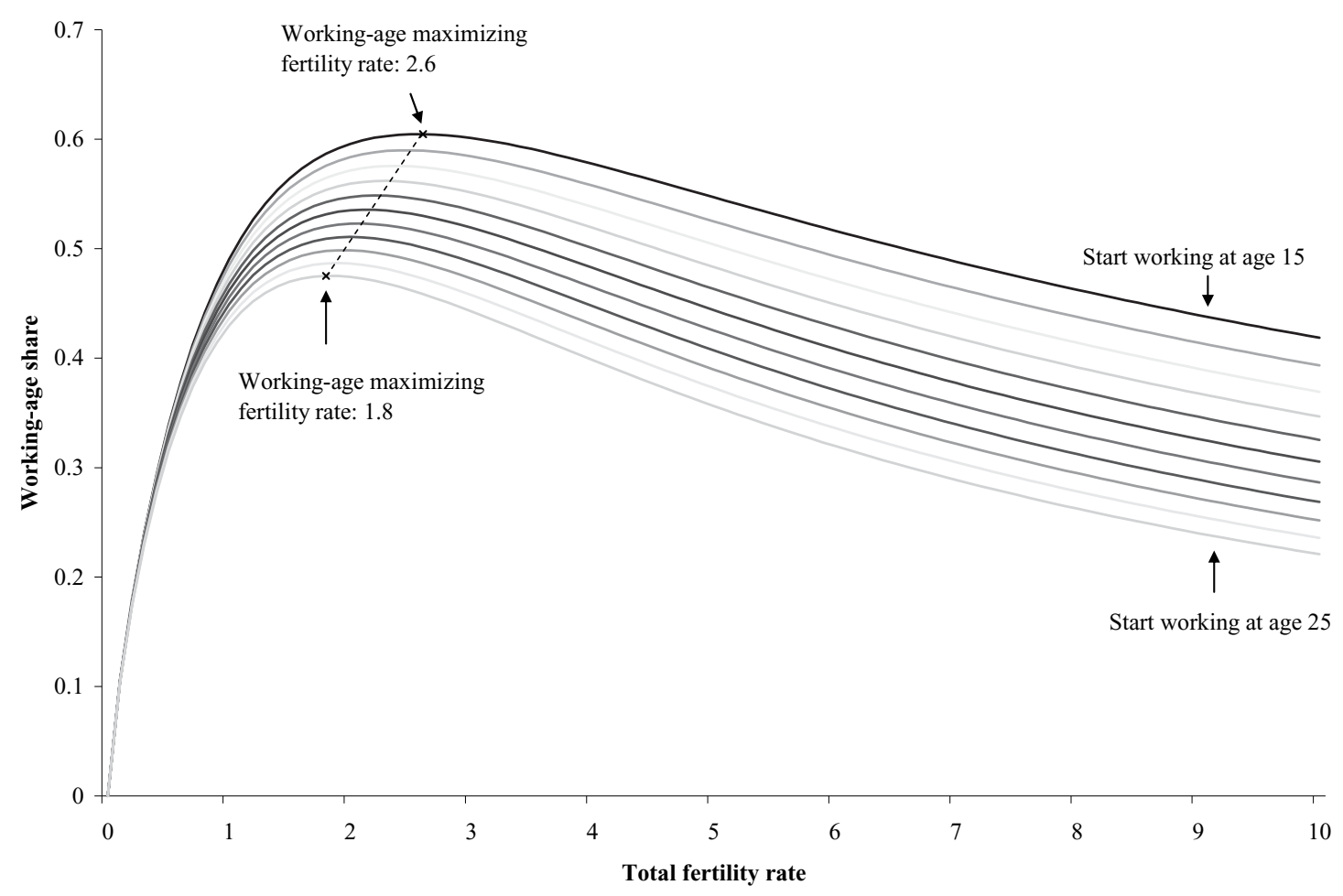

The second main channel omitted in the basic model outlined in this section is immigration. Immigrants generally display reproductive behavior different from the population in their host countries (Fernandez and Fogli, 2006) and also directly affect the age distribution of countries. The exact effect of migration on age structure depends on the average age of the migrants, as well as on the duration of stay. Immigrants arriving during their working age and leaving before retirement increase the relative size of the working-age population and labor force of their host country, and lower the working-age share in their country of origin.

The third main factor we did not consider in our discussion of fertility trajectories that optimize economic growth is behavioral change. Changes in fertility are likely to change labor force participation rates of women (and possibly men too) (Bloom and Freeman, 1986; Bloom, Canning, Fink and Finlay, 2007), but are also likely to lead to changes in the accumulation of 
human and physical capital (Bloom, Canning, Mansfield and Moore, 2007; Lee and Mason, 2008). These factors imply positive externalities generated by low fertility rates in the long run that may partially offset the negative working-age-share effects highlighted here.

\section{Fertility in Western Europe}

In all European countries the 2005 total fertility rate is lower than the 1975 rate, as shown in Table 1. Over the same time period the figures in Table 1 indicate that the working-age share in all European countries (except Finland) has increased. An increase in the working-age share requires the denominator (number of people age 15-64) to grow faster than the numerator (total population). The dynamic effect of a fertility decline on working-age share is highlighted by Bloom, Canning, and Sevilla (2003). An initial decline in fertility will lower the youth dependency ratio and mechanically increase the working-age share. Over a lifetime horizon, the smaller sized cohorts move through the population age groups and the new stable population distribution will be achieved if fertility, mortality, and net migration remain constant. With below-replacement fertility rates we would expect to observe a decline in the working-age share as illustrated in Figure 4. However, this dynamic has not yet materialized in Europe.

Theoretically, in the short term, working-age share could remain high in the face of below-replacement fertility if the mortality rate of the working-age population improves relative to that of the dependent age-groups. In Western Europe, life expectancy improvements have been seen across the board. But improvements are likely to be concentrated in the old-age groups, which will increase old-age dependency and depress, rather than increase, the working-age share.

In Western Europe, the increase in the working-age share between 1975 and 2005 is likely to have been driven by two key factors: immigration and short-run dynamics. Since most immigrants are young (Malmberg, 2008), continued immigration essentially substitutes for low birth rates and increases the relative size of the working-age share. The second main reason for the absence of evidence on the positive relationship between fertility below replacement rates and falling working-age share lies in the fact that most countries with very low total fertility rates 
today have moved below replacement only recently. According to World Development Indicators (World Bank, 2007), only four countries (Czech Republic, Estonia, Hungary, Latvia) had total fertility rates below 2.1 in 1960; in 2005, total fertility was below 2.1 in all European countries. Given that the negative age structure effects of low fertility rates only come through once low fertility persists for several generations (as the age distribution approaches stability), the full effects of the move to low fertility rates will only become apparent several decades from today. In other words: the generations currently retiring in most countries with low fertility rates still bore more than two children on average, which keeps old-age dependency rates moderate. Once the generations who have fewer than two children on average begin to dominate, this balance will change, and there will be a sizable reduction in the working-age share unless a high and continued inflow of (young) immigrants is sustained. 
Table 1: Demographic features of Western European countries 1975 and 2005

\begin{tabular}{|c|c|c|c|c|c|c|}
\hline & Year & $\begin{array}{c}\text { Total fertility } \\
\text { rate } \\
\end{array}$ & $\begin{array}{c}\text { Life } \\
\text { expectancy }\end{array}$ & Net migration & $\begin{array}{c}\begin{array}{c}\text { Working-age } \\
\text { share }\end{array} \\
\end{array}$ & Population \\
\hline \multirow{2}{*}{ Austria } & 1975 & 1.82 & 71.1 & 77,970 & 61.9 & $7,560,000$ \\
\hline & 2005 & 1.41 & 79.4 & 100,000 & 67.8 & $8,230,000$ \\
\hline \multirow[t]{2}{*}{ Belgium } & 1975 & 1.74 & 71.9 & 73,650 & 63.9 & $9,800,000$ \\
\hline & 2005 & 1.72 & 79.5 & 67,000 & 65.6 & $10,500,000$ \\
\hline \multirow[t]{2}{*}{ Denmark } & 1975 & 1.92 & 74.1 & 16,740 & 64.0 & $5,060,000$ \\
\hline & 2005 & 1.80 & 77.8 & 60,613 & 66.2 & $5,420,000$ \\
\hline \multirow[t]{2}{*}{ Finland } & 1975 & 1.69 & 71.7 & 23,210 & 67.4 & $4,710,000$ \\
\hline & 2005 & 1.80 & 78.8 & 41,181 & 66.8 & $5,250,000$ \\
\hline \multirow[t]{2}{*}{ France } & 1975 & 1.93 & 72.8 & 480,960 & 62.6 & $52,700,000$ \\
\hline & 2005 & 1.92 & 80.2 & 300,000 & 65.2 & $60,900,000$ \\
\hline \multirow[t]{2}{*}{ Germany } & 1975 & 1.45 & 71.4 & 888,530 & 63.6 & $78,700,000$ \\
\hline & 2005 & 1.36 & 78.9 & $1,100,000$ & 66.9 & $82,500,000$ \\
\hline \multirow[t]{2}{*}{ Greece } & 1975 & 2.37 & 73.2 & $-72,030$ & 63.9 & $9,050,000$ \\
\hline & 2005 & 1.28 & 79 & 179,000 & 67.5 & $11,100,000$ \\
\hline \multirow[t]{2}{*}{ Ireland } & 1975 & 3.40 & 71.7 & 52,810 & 57.8 & $3,180,000$ \\
\hline & 2005 & 1.88 & 79.4 & 194,000 & 68.9 & $4,160,000$ \\
\hline \multirow[t]{2}{*}{ Italy } & 1975 & 2.21 & 72.6 & $-120,850$ & 63.7 & $55,400,000$ \\
\hline & 2005 & 1.32 & 80.3 & 600,000 & 66.0 & $58,600,000$ \\
\hline \multirow[t]{2}{*}{ Luxembourg } & 1975 & 1.55 & 71.4 & 20,620 & 65.4 & 361,000 \\
\hline & 2005 & 1.70 & 79.2 & 19,567 & 67.3 & 457,000 \\
\hline \multirow[t]{2}{*}{ Netherlands } & 1975 & 1.66 & 74.5 & 152,460 & 63.9 & $13,700,000$ \\
\hline & 2005 & 1.73 & 79.3 & 150,000 & 67.7 & $16,300,000$ \\
\hline \multirow[t]{2}{*}{ Norway } & 1975 & 1.99 & 74.8 & 15,990 & 62.5 & $4,010,000$ \\
\hline & 2005 & 1.84 & 80 & 58,430 & 65.4 & $4,620,000$ \\
\hline \multirow[t]{2}{*}{ Portugal } & 1975 & 2.52 & 69.3 & 9,510 & 62.2 & $9,090,000$ \\
\hline & 2005 & 1.40 & 78.1 & 250,000 & 67.0 & $10,500,000$ \\
\hline \multirow[t]{2}{*}{ Spain } & 1975 & 2.79 & 73.3 & $-73,130$ & 62.4 & $35,500,000$ \\
\hline & 2005 & 1.33 & 80.6 & $2,025,000$ & 69.2 & $43,400,000$ \\
\hline \multirow[t]{2}{*}{ Sweden } & 1975 & 1.78 & 75.0 & 19,440 & 64.2 & $8,190,000$ \\
\hline & 2005 & 1.77 & 80.5 & 157,000 & 65.3 & $9,020,000$ \\
\hline \multirow[t]{2}{*}{ Switzerland } & 1975 & 1.60 & 74.7 & $-10,520$ & 65.0 & $6,410,000$ \\
\hline & 2005 & 1.42 & 81.2 & 40,000 & 67.6 & $7,440,000$ \\
\hline \multirow[t]{2}{*}{ United Kingdom } & 1975 & 1.81 & 72.7 & $-146,110$ & 62.7 & $56,200,000$ \\
\hline & 2005 & 1.80 & 78.9 & 686,400 & 66.1 & $60,200,000$ \\
\hline
\end{tabular}

Source: World Bank (2007) 
The size of the economic repercussions of declining working-age shares on economic development, however, will critically depend on individual behavior. With increasing life expectancies and smaller family sizes many aspects of societies are bound to change.

In Bloom et al (2007) we show that each extra child lowers a female's labor force participation by approximately four years over an average working life. With lower fertility rates, female labor force participation increases and has important positive second-order effects on income per capita. This relationship, however, appears different in European countries, where fertility is clustered in a relatively small range as shown in Figure 7. Engelhardt and Prskawetz (2004) argue that in fact the relationship between fertility and female labor force participation in Europe is positive when looking at the changes within countries across time.

Figure 7: Fertility and Female Labor Force Participation in Europe, 2005

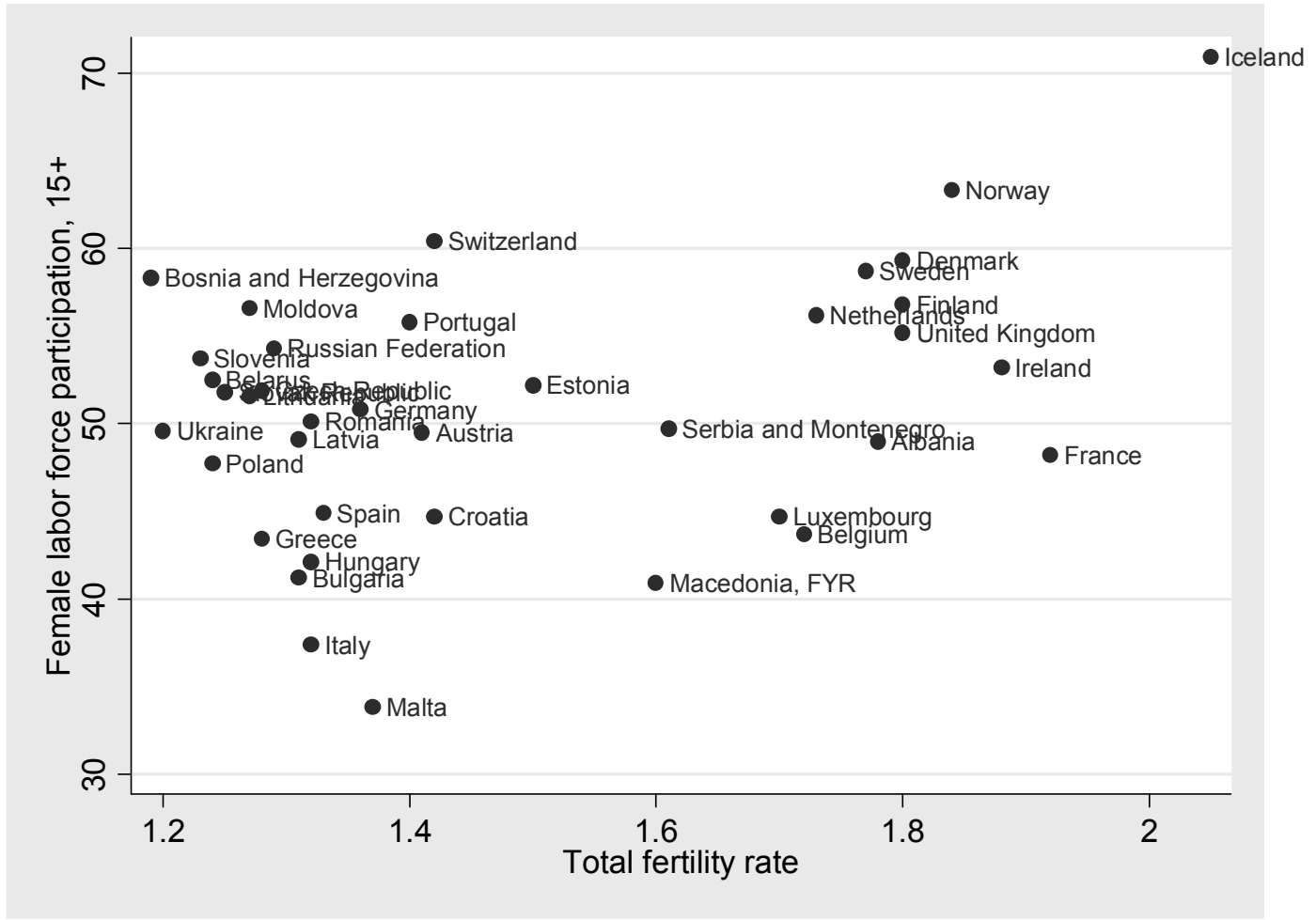

Source: ILO Bureau of Statistics (2007), World Bank (2007)

Changing fertility may also affect savings behavior. From a life-cycle perspective, children and savings can be viewed as substitutes in terms of old-age security. In the absence of 
formal capital markets, children may act as a more reliable form of savings for old-age support than financial savings. As capital markets develop, parents can substitute towards savings and lower the demand for children (Ehrlich and Kim, 2007).

Lee and Mason (2008) argue that smaller family sizes do not necessarily lead to lower aggregate human capital. According to the Lee-Mason model, households contribute a fixed proportion of resources to fund the education of all the children. When the number of children per household declines, investment in each child's education increases proportionally. Accordingly, as these children age and enter the workforce, the aggregate amount of human capital is not compromised even though the number of people entering the workforce is now lower.

\section{Fertility and Income Per Capita in Europe}

In previous studies Bloom, Canning, and others have highlighted the importance of the level and growth rate of the working-age share in explaining cross-country differences in economic growth (Bloom, Canning et al., 2003; Bloom, Canning, Fink and Finlay, 2007; Bloom, Canning, Fink and Finlay, 2007). In this paper we emphasize the role of fertility and examine the direct effect of fertility changes on economic growth in Europe compared to the global sample.

To test the effects of fertility on economic performance in Europe we follow the framework developed in Bloom et al. (2008), and estimate a reduced form of the following type:

$$
\ln \left(y_{i t}\right)=\beta_{0}+\beta_{1} f_{i t}+\xi_{t}+\xi_{i}+\varepsilon_{i t}
$$

where $\ln \left(y_{i t}\right)$ is the natural logarithm of income per capita (measured in constant prices at PPP), $f_{i t}$ is the total fertility rate of country $i$ in period $t$, and $\xi_{t}$ and $\xi_{i}$ are year and country dummies, respectively. The unobserved country- and time-specific factors are captured in the residual, $\varepsilon_{i t}$.

In this reduced form estimation approach we omit variables such as life expectancy and growth of the working-age share that have been highlighted in previous works as an important 
explanatory factor of economic development (Bloom, Canning et al., 2003; Bloom, Canning and Sevilla, 2004). Rather than choosing among the large set of potential factors explaining income differentials across countries, we follow the reduced from approach chosen by Acemoglu and Johnson (2007) and rely on exogenous changes in fertility to identify the causal effect of fertility on income.

To instrument for total fertility in equation (4) we use international abortion laws. The national abortion legislation data are published on an annual basis by the United Nations Population Division (2002). We code the abortion laws into an index ranging from 0 to 7 , with higher values of the abortion index indicating more liberal abortion legislation. ${ }^{10}$ For further description of the abortion data and the validity of the abortion index as an instrument for fertility see Bloom et al. (2007) and Bloom et al. (2008).

In the empirical results presented here, we focus on two main samples: a Western European sample comprising the former EU15 plus Norway and Switzerland, and a European sample with all 36 countries in Western and Eastern Europe. The sample period covers the years 1960-2000, which we divide into five-year intervals. Table 2 shows the descriptive statistics for the two sub-samples. A full country list is provided in the appendix, Table A1. As Table 2 shows, the two samples look fairly similar, with the Western European part being richer in terms of real income per capita, and the Eastern European countries displaying slightly lower fertility rates and slightly more liberal abortion laws.

The analysis we conduct suggests that the effect of fertility on income per capita differs across country sub-samples. In Bloom et al (2008) we find that fertility has a negative effect on income per capita in a global sample. In the European sample presented below, we find that there is a positive effect of fertility increases on income per capita. This could lead us to a more sophisticated estimation framework that is non-linear in fertility versus a structural break at a Hansen-tested threshold (Hansen, 1999; 2000; 2004). However, we choose to estimate the specification as outlined in equation (6) as the non-linearity is difficult to identify with only one

\footnotetext{
${ }^{10}$ An index value of 0 means that abortion is not allowed on any legal ground. An index value of 7 means that abortion is legal for all of the following reasons: life-threatening condition, mother's mental health, mother's physical health, rape or incest, fetal impairment, economic reasons, and on request.
} 
instrumental variable. Moreover, OLS estimation of a non-linearity compared to a structural break indicates that there is little difference between the suggested marginal impact from a nonlinear model as compared to a model with a split ${ }^{11}$.

\section{Table 2: Descriptive statistics}

\begin{tabular}{lcccc} 
Western Europe & & & \\
\hline \hline \multicolumn{1}{l}{ Mean } & Std. Dev. & Min & Max \\
\hline ln(GDP per capita) & 9.65 & 0.44 & 8.21 & 10.78 \\
Total fertility rate & 1.98 & 0.58 & 1.18 & 4.03 \\
Abortion index & 4.42 & 2.53 & 1.00 & 7.00 \\
\hline Based on 144 observations, 17 countries & & & \\
\hline \hline & & & & \\
Europe & & & Max \\
\hline \hline & Mean & Std. Dev. & Min & \\
\hline ln(GDP per capita) & 9.39 & 0.64 & 7.14 & 10.78 \\
Total fertility rate & 1.92 & 0.55 & 1.10 & 4.03 \\
Abortion index & 4.98 & 2.51 & 0.00 & 7.00 \\
\hline Based on 217 observations, 36 countries & & & \\
\hline \hline
\end{tabular}

Table 3 shows the results for our main specification. In columns 1 and 2 we estimate equation (4) with OLS; in columns 3 and 4 we use the abortion index to instrument for fertility. Column 1 and 3 control for period fixed effects only, while columns 2 and 4 show the more robust specifications with time and country fixed effects. Although we find some evidence for a negative effect of fertility on income per capita consistent with our previous work in the extended sample (2008), this effect does not appear to be significant in the IV estimation with fixed effects shown in column 4 of Table 3. The complete results of the first stage are available in Appendix Table A2. It should be noted, though, that our sample is very small here, making identification in the first stage difficult. In the larger European sample with 36 countries, our instrument performs better in the first stage; a Cragg-Donald statistic of 7.1 implies that our instrument predicts fertility reasonably well in the first stage with time and country fixed effects.

\footnotetext{
${ }^{11}$ These results are not presented in this paper, but are available on request.
} 
The estimated coefficient on fertility is positive and significant at 0.5 , meaning that a unit increase in fertility in this sample implies a 50\% increase in output per capita.

The positive effect of a fertility increase on income per capita contrasts with the strong and negative relationship found between fertility and income in an extended set of countries (Bloom, Canning et al., 2008). Since the European sample is almost entirely characterized by fertility rates below replacement, this is consistent with the basic mechanism outlined in section 2. Although increases in fertility have negative effects on output per capita in a high-fertility environment, the opposite seems to be true in an environment with fertility rates below replacement, as has been previously noted for a smaller sample (Hondroyiannis and Papapetrou, 2005).

Table 3: Fertility and GDP per capita

Western Europe

\begin{tabular}{lllll}
\hline \hline Dependent variable: $\ln (\mathrm{GPD} / \mathrm{P})$ & $(1)$ & $(2)$ & $(3)$ & $(4)$ \\
\hline Total fertility rate & $-0.315^{* * *}$ & -0.0709 & $-0.579^{* * *}$ & -0.173 \\
& -0.051 & $(0.049)$ & $(0.12)$ & $(0.28)$ \\
Year dummies & Yes & Yes & Yes & Yes \\
Country fixed effects & No & Yes & No & Yes \\
Estimation method & OLS & OLS & IV & IV \\
R-squared & 0.64 & 0.96 & 0.59 & 0.95 \\
Cragg-Donald F-stat & & & 25.40 & 1.547 \\
\hline
\end{tabular}

Notes:

Robust standard errors in parentheses; $* * * \mathrm{p}<0.01, * * \mathrm{p}<0.05, * \mathrm{p}<0.1 ; 1169$ observations

Europe

\begin{tabular}{lllll}
\hline \hline Dependent variable: $\ln (\mathrm{GPD} / \mathrm{P})$ & $(1)$ & $(2)$ & $(3)$ & $(4)$ \\
\hline Total fertility rate & $-0.310^{* * *}$ & $0.0958^{*}$ & 0.360 & $0.555^{* *}$ \\
& -0.11 & $(0.056)$ & $(0.35)$ & $(0.25)$ \\
Year dummies & Yes & Yes & Yes & Yes \\
Country fixed effects & No & Yes & No & Yes \\
Estimation method & OLS & OLS & IV & IV \\
R-squared & 0.14 & 0.96 & -0.02 & 0.93 \\
Cragg-Donald F-stat & & & 26.49 & 7.114 \\
\hline
\end{tabular}

Notes:

Robust standard errors in parentheses; $* * * \mathrm{p}<0.01, * * \mathrm{p}<0.05, * \mathrm{p}<0.1 ; 1169$ observations 


\section{Discussion}

In this paper we have explored the effect of fertility on income per capita in the short and long run. In the short run, a decline in the fertility rate unambiguously increases income per capita as youth dependency falls and the working-age share increases. As we have shown in the theoretical framework presented in section 2 of this paper, the relationship between fertility and age structure in steady-state is more complex in the long run. Although it is true that very high fertility rates have a negative effect on output per capita through low working-age shares, the positive effect of lowering fertility only exist up to the rate at which working-age share is maximized; any fertility decline below this maximizing rate lowers the working-age share in equilibrium and may induce a reduction in output per capita consistent with our findings in section 4 of this paper. In high-fertility countries such as Zambia, the message is clear: lower fertility will increase income per capita. For low-fertility European countries, the implications of fertility decline are more complex: lower fertility will increase income per capita in the short run, but decrease it in the long run. This poses a policy conundrum for European policymakers.

In most Western European countries, continued net immigration and the relatively recent decline in fertility have bolstered working-age shares to today's levels. However, given the growing aversion to further immigration exhibited in many European countries and the resulting increase in migration restrictions, the scope for large future immigration inflows seems very limited at the moment. If fertility rates stay at current levels, or fall further, declines in the working-age share of the population will occur over the next decades and depress income per capita gains. With a life expectancy of 80 years, our simulations imply that the long-run working-age shares will drop to somewhere between $50 \%$ and $55 \%$ if fertility rates stay at current levels. Comparing this with the current working-age shares close to $70 \%$ in most European countries implies a reduction in the number of workers per capita of around $25 \%$ under the assumption that average participation rates remain unchanged. Even though this adjustment is likely to happen over several decades, the resulting negative growth effects will clearly be noticed, especially by those economies with already modest economic growth. 
The exact magnitude of these effects, however, critically depends on the multitude of policies affecting labor force participation, particularly social security regulations (Gruber and Wise, 1998; Blondal and Scarpetta, 1999; Gruber and Wise, 1999; Gruber and Wise, 2004). Adjusting institutional settings such as social security, child care, and education will not only be important to ensure long-term fiscal sustainability, but also to lessen and possibly avoid negative income effects generated by demographic change. 


\section{References}

Aarssen, L. W. (2005). "Why is fertility lower in wealthier countries? The role of relaxed fertility-selection." Population and Development Review 31(1): 113-126.

Acemoglu, D. and S. Johnson (2007). "Disease and Development: The effect of life expectancy on economic growth." Journal of Political Economy 115(6): 925-985.

Adsera, A. (2006). "An economic analysis of the gap between desired and actual fertility: The case of Spain." Review of Economics of the Household 4: 75-95.

Adsera, A. (2006). "Marital fertility and religion in Spain, 1985-1999." Population Studies 60(2): 205-221.

Becker, G. S., E. L. Glaeser and K. M. Murphy (1999). "Population and economic growth." American Economic Review 89(2): 145-49.

Billari, F., T. Frejka, J. Hobcraft, M. Macura and D. J. van de Kaa (2004). "Discussion of paper 'Explanations of the fertility crisis in modern societies: A search for commonalities Population Studies 57(3): 241-263, by John Caldwell and Thomas Schindlmayr'." Population Studies 58(1): 77-92.

Billari, F. and H.-P. Kohler (2004). "Patterns of low and lowest-low fertility in Europe." Population Studies 58(2): 161-176.

Bjorklund, A. (2006). "Does family policy affect fertility? Lessons from Sweden." Journal of Population Economics 19: 3-24.

Blondal, S. and S. Scarpetta (1999). "The Retirement Decision in OECD Countries." OECD Economics Department Working Paper 202.

Bloom, D. E., D. Canning, G. Fink and J. E. Finlay (2007). "Does Age Structure Forecast Economic Growth?" International Journal of Forecasting. 23: 569-585.

Bloom, D. E., D. Canning, G. Fink and J. E. Finlay (2007). " Fertility, Female Labor Force Participation, and the Demographic Dividend." NBER Working Paper 13583.

Bloom, D. E., D. Canning, G. Fink and J. E. Finlay (2007). "Realizing the Demographic Dividend: Is Africa any Different?" PGDA working paper 23.

Bloom, D. E., D. Canning, G. Fink and J. E. Finlay (2008). "The Effect of Fertility on Economic Growth." Working Paper.

Bloom, D. E., D. Canning, R. K. Mansfield and M. Moore (2007). "Demographic Change, Social Security Systems and Savings." Journal of Monetary Economics 54: 92-114.

Bloom, D. E., D. Canning and J. Sevilla (2003). "The Demographic Dividend: A New Perspective on the Economic Consequences of Population Change." Population Matters Monograph MR-1274, RAND, Santa Monica.

Bloom, D. E., D. Canning and J. Sevilla (2004). "The Effect of Health on Economic Growth: A Production Function Approach." World Development 32(1): 1-13.

Bloom, D. E. and R. B. Freeman (1986). "The Effects of Rapid Population Growth on Labor Supply and Employment in Developing Countries." Population and Development Review 12(3): 381-414.

Bloom, D. E. and R. B. Freeman (1988). "Economic Development and the Timing and Components of Population Growth." Journal of Policy Modeling 10.

Bongaarts, J. and R. A. Bulatao (1999). "Completing the Demographic Transition." Population and Development Review 25(3): 515--529.

Brander, J. A. and S. Dowrick (1994). "The Role of Fertility and Population in Economic Growth." Journal of Population Economics 7(1): 1-25. 
Coleman, D. (2006). "Immigration and ethnic change in low-fertility countries: A third demographic transition." Population and Development Review 32(3): 401-446.

Deardorff, A. V. (1976). "The Opimum Growth Rate for Population: Comment." International Economic Review 17(8): 510-515.

Ehrlich, I. and J. Kim (2007). "Has Social Security Influenced Family Formation and Fertility in OECD Countries? An Economic and Econometric Analysis." NBER Working Paper 12869.

Ehrlich, P. R. (2008). "Demography and Policy: A View from Outside the Discipline." Population and Development Review 34(1): 103-113.

Engelhardt, H. and A. Prskawetz (2004). "On the changing correlation between fertility and female employment over space and time." European Journal of Population 20: 35-62.

Fernandez, R. and A. Fogli (2006). "Fertility: The Role of Culture and Family Experience." Journal of the European Economic Association 4(2): 552-561.

Feyrer, J., B. Sacerdote and A. D. Stern (2007). "Will the Stork Return to Europe? Understanding fertility within developed nations." Mimeo.

Galor, O. (2005). "The demographic transition and the emergence of sustained economic growth." Journal of European Economic Association 3(2-3): 494-504.

Galor, O. and D. N. Weil (1999). "From Malthusian stagnation to modern growth." American Economic Review 89(2): 150-154.

Galor, O. and D. N. Weil (2000). "Population, Technology, and Growth: From Malthusian Stagnation to the Demographic Transition and Beyond." American Economic Review 90(4): 806-28.

Garrido, L. J. and M. A. Malo (2005). "Postponement of family formation and public budget: Another approach to very low fertility in Spain." Public Finance and Management 5(1): 152-177.

Gruber, J. and D. Wise (1998). "Social Security and Retirement: An International Comparison." The American Economic Review 88(2): 158-163.

Gruber, J. and D. A. Wise (1999). Social Security and Retirement around the World. Chicago, The University of Chicago Press.

Gruber, J. and D. A. Wise (2004). Social Security Programs and Retirement around the World: Micro-Estimation. Chicago, The University of Chicago Press.

Hansen, B. E. (1999). "Threshold effects in non-dynamic panels: Estimation, testing, and inference." Journal of Econometrics 93: 345-368.

Hansen, B. E. (2000). "Sample Splitting and Threshold Estimation." Econometrica 68(3): 575603.

Hansen, B. E. (2004). "Instrumental Variable Estimation of a Threshold Model." Econometric Theory 20: 813-843.

Hondroyiannis, G. and E. Papapetrou (2005). "Fertility and output in Europe: new evidence from panel cointegration analysis." Journal of Policy Modeling 27: 143-156.

ILO Bureau of Statistics (2007). ILO Database on Labour Statistics, International Labour Organization.

Kelley, A. C. (1988). "Economic consequences of population change in the third world." Journal of Economic Literature 26: 1685-1728.

Kelley, A. C. and R. M. Schmidt (1995). "Aggregate Population and Economic Growth Correlations: The Role of the Components of Demographic Change." Demography 32(4): 543-555. 
Kohler, H.-P. (2006). "Determinants of Low Fertility in Europe." Entre Nous 63.

Kohler, H.-P., F. C. Billari and J. A. Ortega (2002). "The emergence of lowest-low feriltiy in Europe during the 1990s." Population and Development Review 28(4): 641-680.

Lee, R. and A. Mason (2008). "Fertility, Human Capital, and Economic Growth over the Demographic Transition." Mimeo.

Lesthaneghe, R. and P. Willems (1999). "Is low fertility a temporary phenomenon in the European Union?" Population and Development Review 25(2): 211-228.

Lutz, W. and V. Skirbekk (2005). "Policies addressing the tempo effect in low-fertility countries." Population and Development Review 31(4): 699-720.

Malmberg, B. (2008). Global Population Ageing, Migration and European External Policies. Stockholm, Institute for Future Studies.

McDonald, P. (2006). "Low Fertility and the State: The Efficacy of Policy." Population and Development Review 32(3): 485-510.

McDonald, P. (2008). "Very Low Fertility: Consequences, Causes and Policy Approaches." The Japanese Journal of Population 6(1).

Samuelson, P. A. (1975). "The Optimum Growth Rate for Population." International Economic Review 16(3): 531-538.

Samuelson, P. A. (1976). "The Optimum Growth Rate for Population: Agreement and Evaluations." International Economic Review 17(2): 516-525.

Simon, J. L. (1996). The Ultimate Resource 2. Princeton, Princeton University Press.

Solow, R. M. (1956). "A Contribution to the Theory of Economic Growth." Quarterly Journal of Economics 70: 65-94.

United Nations Population Division. (2002). "Abortion Policies: A Global Review." 2007, from http://www.un.org/esa/population/publications/abortion/index.htm.

World Bank (2007). World Bank Development Indicators CD-ROM.

World Health Organization Life Tables for WHO Member States. 


\section{Appendix}

\section{Table A1: Country list}

\begin{tabular}{llll}
\hline \hline Albania 1990-2000 & Finland*1975-2000 & Macedonia, FYR 1990-2000 & Slovenia 1990-2000 \\
Austria* 1975-2000 & France* 1960-2000 & Malta 1970-2000 & Spain* 1960-2000 \\
Belarus 1995-2000 & Germany* 1970-2000 & Moldova 1995-2000 & Sweden* 1960-2000 \\
Belgium* 1960-2000 & Greece* 1960-2000 & Netherlands* 1960-2000 & Switzerland* 1960-2000 \\
$\begin{array}{l}\text { Bosnia \& Herzegovina 1990-2000 } \\
\text { Bulgaria 1995-2000 }\end{array}$ & Hungary 1970-2000 & Norway* 1965-2000 & Ukraine 1995-2000 \\
Croatia 1990-2000 & Iceland 1975-2000 & Poland 1970-2000 & United Kingdom* 1960-2000 \\
Czech Republic 1990-2000 & Ireland* 1960-2000 & Portugal* 1960-2000 & \\
Denmark* 1960-2000 & Italy* 1960-2000 & Romania 1960-2000 & \\
Estonia 1990-2000 & Lithuania 1995-2000 & Russian Federation 1990-2000 & \\
\hline Note: * In Western European sample & Suxembourg* 1960-2000 & & \\
\hline \hline
\end{tabular}




\section{Table A2: First stage}

Western Europe

\begin{tabular}{lll}
\hline \hline Dependent variable: Total fertility rate & $(3)$ & $(4)$ \\
\hline Abortion law index & $-0.0759^{* * *}$ & -0.0213 \\
& -0.017 & $(0.018)$ \\
Year dummies & Yes & Yes \\
Country fixed effects & No & Yes \\
R-squared & 0.66 & 0.84 \\
\hline
\end{tabular}

Notes:

Robust standard errors in parentheses; ${ }^{* * *} \mathrm{p}<0.01,{ }^{* *} \mathrm{p}<0.05,{ }^{*} \mathrm{p}<0.1$;

144 observations

Europe

\begin{tabular}{lll}
\hline \hline Dependent variable: Total fertility rate & $(3)$ & $(4)$ \\
\hline Abortion law index & $-0.0612^{* * *}$ & $-0.0398^{* *}$ \\
& -0.013 & $(0.018)$ \\
Year dummies & Yes & Yes \\
Country fixed effects & No & Yes \\
R-squared & 0.59 & 0.81 \\
\hline
\end{tabular}

Notes:

Robust standard errors in parentheses; $* * * p<0.01, * * p<0.05, * \mathrm{p}<0.1$; 217 observations 